\title{
Roles of Eastern Siberian Mountain Ranges in Precipitation - Verkhoyansk, Dzhugdzhur and Stanovoy Mountain Ranges -
}

\author{
Ryuhei Yoshida, Masahiro Sawada and Takeshi Yamazaki \\ Graduate School of Science, Tohoku University, Sendai, Japan
}

\begin{abstract}
Precipitation amounts of three Lena mountain ranges (Verkhoyansk, Dzhugdzhur and Stanovoy) were investigated using numerical simulations for three months. First, we examined the precipitation distribution in eastern Siberia using routine station data. A north-south precipitation gradient was found, with the greatest precipitation in a southern area, and $47 \%$ of precipitation occurring in June, July, and August.

To isolate the roles of the three Lena mountain ranges in determining precipitation, especially the north-south precipitation gradient, we conducted mountain removal experiments to examine differences in precipitation from the results of a real topography experiment. Results show that the Verkhoyansk (northeast of the Lena Basin) and Dzhugdzhur Mountain Range (southeast) had a weak effect on the north-south precipitation gradient. It was caused by relatively low specific humidity for Verkhoyansk and low elevation for Dzhugdzhur mountain range. The Stanovoy mountain range (south) exhibited a strong effect with higher specific humidity and elevation. Thus Stanovoy mountain range has the most contribution to north-south precipitation gradient among three Lena mountain ranges.
\end{abstract}

\section{Introduction}

Eastern Siberia is surrounded by the Verkhoyansk, Dzhugdzhur and Stanovoy mountain ranges. Precipitation in eastern Siberia, which is closely correlated to water vapor transport, is affected by the existence of these mountain ranges.

Precipitation is a key factor for tree growth. Positive correlation was found between precipitation and the Normalized Difference Vegetation Index (NDVI) from $60^{\circ} \mathrm{N}$ to $75^{\circ} \mathrm{N}$ along $130^{\circ} \mathrm{E}$ (Suzuki et al. 2000). High levels of precipitation in the southern area engendered large NDVI. Of course, the opposite is true as well. The possibility exists that orographic precipitation explains the relation.

Precipitation characteristics for western Siberia have been investigated (Frey and Smith 2003; Fukutomi et al. 2007; Iwao and Takahashi 2008), but many characteristics of eastern Siberia remain unclear, especially the relation between water fields, including precipitation, and the existence of mountain ranges. We can examine the roles of mountain ranges through comparison of numerical calculations with and without mountain ranges. This study was undertaken to clarify how precipitation changes with removal of three eastern Siberia mountain ranges and what precipitation type is dominant for these mountain ranges.

\section{Precipitation distribution over eastern Siberia}

We examined the precipitation distribution using routine station data, which are Baseline Meteorological Data in Siberia (BMDS, Suzuki et al. 2004). The distribution of the June, July, and August (JJA) mean precipitation for 1986-2004 is presented

Corresponding author and present affiliation: Ryuhei Yoshida, Division of Agro-Meteorology, National Institute for Agro-Environmental Science, 3-1-3, Kannondai, Tsukuba, Ibaraki 305-8604, Japan. E-mail: ryuhei@ affrc.go.jp. (C)2011, the Meteorological Society of Japan.

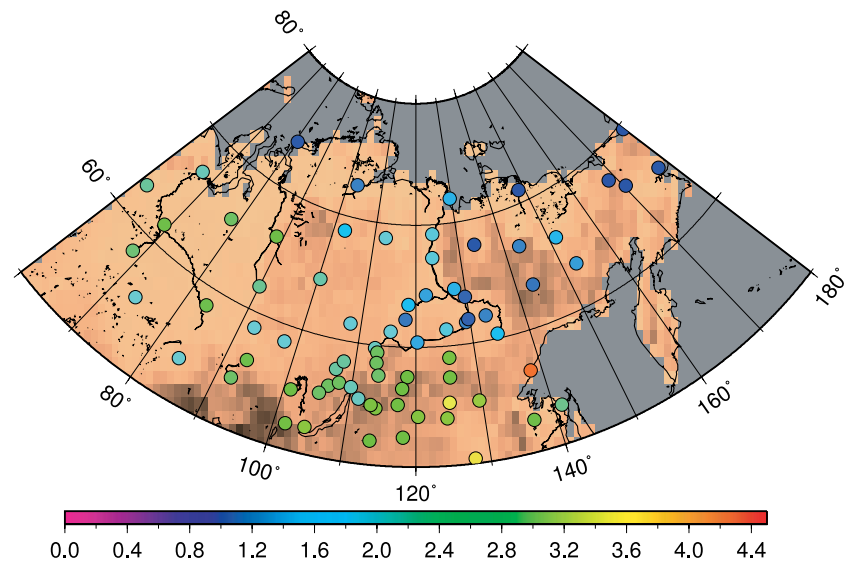

Fig. 1. Distribution of June, July, and August (JJA) averaged precipitation in eastern Siberia using BMDS $\left(\mathrm{mm}^{-1}{ }^{-1}\right)$ for $1986-$ 2004. Rainbow colored circles denote JJA averaged daily precipitation $\left(\mathrm{mm}\right.$ day $\left.{ }^{-1}\right)$. Brown coloration corresponds to topography: light colors show low elevation; dark colors show high elevation.

in Fig. 1. A north-south precipitation gradient was found for eastern Siberia overall. In the middle Lena Basin $\left(60^{\circ} \mathrm{N}-65^{\circ} \mathrm{N}, 110^{\circ} \mathrm{E}\right.$ $-135^{\circ} \mathrm{E}$ ), the averaged JJA precipitation was around $1.2 \mathrm{~mm}$ day $^{-1}$, increasing to $2.8 \mathrm{~mm}^{\text {day }}{ }^{-1}$ south of $60^{\circ} \mathrm{N}$.

Although a north-south precipitation gradient was found for the March, April and May (MAM) mean and for the September, October, and November (SON) mean, it appeared to be weak in winter. Precipitation in winter was smaller than in other seasons, so the contribution to annual precipitation is weak. In December, January, and February (DJF), the area-averaged precipitation was $0.40 \mathrm{~mm} \mathrm{day}^{-1}\left(36 \mathrm{~mm} 90\right.$ day $\left.^{-1}\right)$ and it was $12.0 \%$ of annual precipitation. Similarly, the ratio of seasonal precipitation to annual precipitation was $15.7 \%$ in MAM, $25.5 \%$ in SON, and $46.7 \%$ in JJA. Consequently, almost half of precipitation occurs in JJA. Therefore, to identify why precipitation follows this spacial distribution, we focus on the JJA season.

\section{Numerical model}

In this study, we used Japan Meteorological Agency Nonhydrostatic model (JMA-NHM, Saito et al. 2007). The number of grid points was $141 \times 141$ with $30 \mathrm{~km}$ grid spacing. Considering that almost half of the precipitation occurs during June-August, as mentioned in the previous section, numerical calculations were conducted for JJA. To choose a typical year of precipitation amount, the targeted year was selected as follows. For the area shown in Fig. 2a, the all sites and JJA averaged BMDS precipitation for 1986-2004 was calculated first, the nearest precipitation multi-year periods to the 1986-2004 averaged BMDS precipitation were selected as the targeted years. The derived averaged precipitation rate was $2.06 \mathrm{~mm}^{\text {day }^{-1}}$. JJA of 1990, 2001, 2002 and 2003 were selected as the targeted periods for numerical simulation because JJA averaged daily precipitations were 2.04, 2.01, 1.99 and $2.06 \mathrm{~mm} \mathrm{day}^{-1}$, respectively. Numerical calculation started from one month earlier than JJA for initialization of soil 
(a) CTL

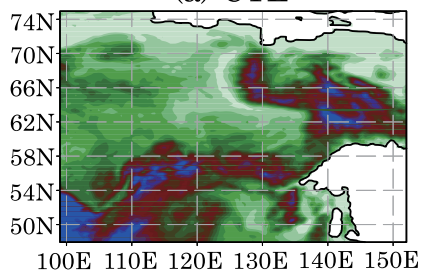

(c) NDM

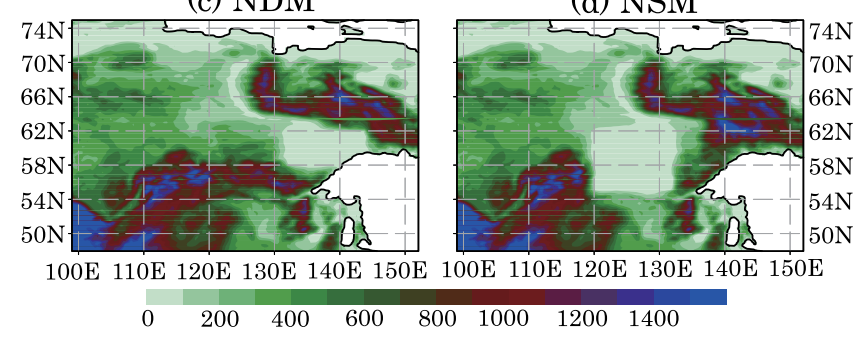

Fig. 2. Topography settings for each experiment. (a) Control (CTL), (b) Without the Verkhoyansk Mountain Range (NVM), (c) Without the Dzhugdzhur Mountain Range (NDM), (d) Without the Stanovoy Mountain Range (NSM). The color bar denotes elevation (m).

water because importance of soil water recycling to precipitation is reported for eastern Siberia (e.g., Kurita et al. 2004; van der Ent et al. 2010). We excluded May as spin-up and used ensemble mean of 1990, 2001, 2002 and 2003 JJA for analysis.

The run with the original topography of the global digital elevation model with a horizontal grid spacing of 30 arc seconds (GTOPO30, U. S. Geological Survey 1996) is called the control (CTL) run. By modifying the CTL topography (Fig. 2a), three topography data were used to examine roles of mountain ranges in precipitation. Figures $2 \mathrm{~b}-2 \mathrm{~d}$ show the other three topographies: (b) without (w/o) Verkhoyansk Mountain Range $\left(63^{\circ} \mathrm{N}-71^{\circ} \mathrm{N}\right.$, $\left.124^{\circ} \mathrm{E}-136^{\circ} \mathrm{E}\right)$, (c) w/o Dzhugdzhur Mountain Range $\left(58^{\circ} \mathrm{N}-\right.$ $62^{\circ} \mathrm{N}, 132^{\circ} \mathrm{E}-144^{\circ} \mathrm{E}$ ) and (d) w/o the Stanovoy Mountain Range $\left(55^{\circ} \mathrm{N}-62^{\circ} \mathrm{N}, 120^{\circ} \mathrm{E}-132^{\circ} \mathrm{E}\right)$. Target elevations were decreased to $1 \%$ of original elevations. We conducted smoothing to boundary of targeted area and its outer area. Fourteen grids from each boundary were excluded for analysis as dumping layer. For simplicity, each topography run is denoted, respectively, as the NVM, NDM, NSM runs. Differences between each mountain range removal run and CTL run show the roles that each mountain range has. Other model settings are shown in Table 1.

\section{Results and discussion}

The CTL run was used to validate the calculated precipitation amount and its distribution. Figure 3 presents a distribution of JRA-25 and the calculated precipitation. A large precipitation amount (near $4 \mathrm{~mm} \mathrm{day}^{-1}$ ) was found on the Stanovoy range in JRA-25 (Fig. 3a, see Fig. 2 for the mountain range location). Precipitation in the Verkhoyansk and Dzhugdzhur Mountain Range was smaller than that in the Stanovoy Mountain Range. Although the CTL run reasonably simulated the JRA-25 precipitation pattern, the amount was underestimated. Area-averaged precipitation was $1.20 \mathrm{~mm} \mathrm{day}^{-1}$ for the CTL run, and $1.81 \mathrm{~mm} \mathrm{day}^{-1}$ for JRA-25. The regional model simulated precipitation was $66.3 \%$ of JRA-25 precipitation.

Following simulations were conducted to examine underestimation of precipitation. Kain-Fritsch scheme contains conversion threshold of condensation water, $q_{\mathrm{c} 0}$. With increase of $q_{\mathrm{c} 0}$, precipitation is expected to increase directly. We conducted sensitivity experiment of $q_{\mathrm{c} 0}=2 \times 10^{-3}$ (CTL run) and $5 \times 10^{-4}$ for $1990 \mathrm{JJA}$ as example. Regional averaged precipitation increased from $1.23 \mathrm{~mm} \mathrm{day}^{-1}$ to $1.37 \mathrm{~mm} \mathrm{day}^{-1}$, however, JRA-25
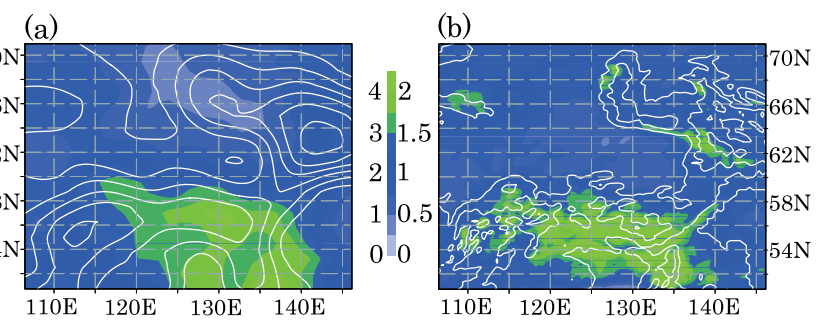

Fig. 3. Distribution of 1990, 2001, 2002 and 2003 JJA averaged daily precipitation for (a) JRA-25 reanalysis data and (b) CTL run $\left(\mathrm{mm}\right.$ day $\left.^{-1}\right)$. The contour shows the topography. Shading shows the precipitation amount $\left(\mathrm{mm} \mathrm{day}^{-1}\right)$. The topography is drawn (a) using 1.25 deg grid spacing topography data for JRA-25, (b) 30 $\mathrm{km}$ grid spacing topography used for numerical simulation.

precipitation was $2.03 \mathrm{~mm}^{-1}{ }^{-1}$ thus precipitation was not sensitive regardless of the value of threshold $q_{\mathrm{c} 0}$. There is a possibility that precipitation underestimation was caused by weak convection or water vapor flux convergence. However, the distribution itself was simulated similarly to reanalysis data. Since the JRA-25 precipitation is also simulated, the effect of regional model underestimation is not a hindrance to the following discussion.

\subsection{Verkhoyansk mountain range}

The Verkhoyansk Mountain Range $\left(63^{\circ} \mathrm{N}-71^{\circ} \mathrm{N}, 124^{\circ} \mathrm{E}-\right.$ $\left.136^{\circ} \mathrm{E}\right)$ is located in north of the middle Lena Basin. As shown in Fig. 4a, the precipitation area over the Verkhoyansk Mountain Range that had been found in CTL run decreased in the NVM run. The degree of precipitation decrease was mainly ranging from $0.5 \mathrm{~mm} \mathrm{day}^{-1}$ to $1.1 \mathrm{~mm}^{-1 a y}{ }^{-1}$ over the Verkhoyansk Mountain Range. The maximum precipitation decrease was simulated in the northern and southern parts of Verkhoyansk Mountain Range, where the topography slope was steeper than other slopes. Therefore, the precipitation over Verkhoyansk Mountain Range occurred mainly by an orographic effect. Because of the mountain removal, the wind speed was increased in the NVM run compared with that of the CTL run (not shown). Specific humidity, which is an index of the source of precipitation, was around $0.004 \mathrm{~kg}^{-1}$ in the Verkhoyansk Mountain Range, smaller than in the southern area. Consequently, a small impact was made on precipitation for removal of the Verkhoyansk Mountain Range.

Figure 5 shows the cross-section of specific humidity across $66^{\circ} \mathrm{N}$. The line for which specific humidity was $0.005 \mathrm{~kg} \mathrm{~kg}^{-1}$ existed near surface in the area of $120^{\circ} \mathrm{E}$ to $135^{\circ} \mathrm{E}$ for the NVM run. It existed above $950 \mathrm{hPa}$ in the CTL run; therefore, specific humidity was decreased for the NVM run. The middle Lena Basin was moistened by the existence of Verkhoyansk Mountain Range running east-west.

Figure 6 shows a zonal mean from $110^{\circ} \mathrm{E}$ to $140^{\circ} \mathrm{E}$ precipitation rates, its difference from the CTL run, and topography for each experiment. The impact of the Verkhoyansk Mountain Range

Table 1. Model settings.

\begin{tabular}{ll}
\hline Model & JMA-NHM (Saito et al. 2007) \\
Grid size & $30 \mathrm{~km}$ with 141 grids \\
Time step & $60 \mathrm{~s}$ \\
IC, BC & JRA-25 (Onogi et al. 2007) \\
Duration & 1st May 00 UTC-1st September 00 UTC of 1990, \\
& 2001, 2002 and 2003 \\
Vertical layer & 38 layers Stretching grid from 40 to 760 m \\
Moist process & $\begin{array}{l}\text { Kain-Fritsch Scheme (Kain 2004) and cloud micro- } \\
\text { physical processes }\end{array}$ \\
Turbulent process & $\begin{array}{l}\text { Improved Mellor-Yamada Level 3 (Nakanishi and } \\
\text { Niino 2004) }\end{array}$ \\
\hline
\end{tabular}

IC, Initial Condition: BC, Boundary Condition. 
(a)

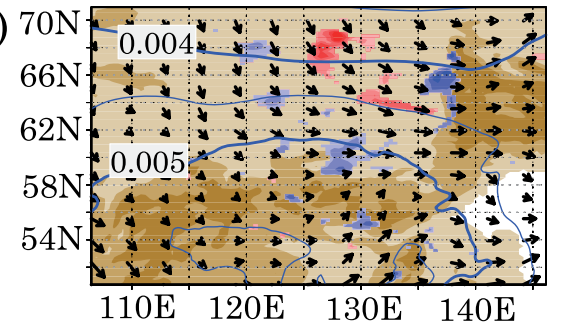

(b)

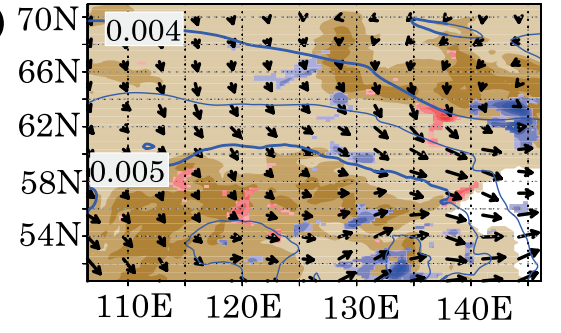

(c)

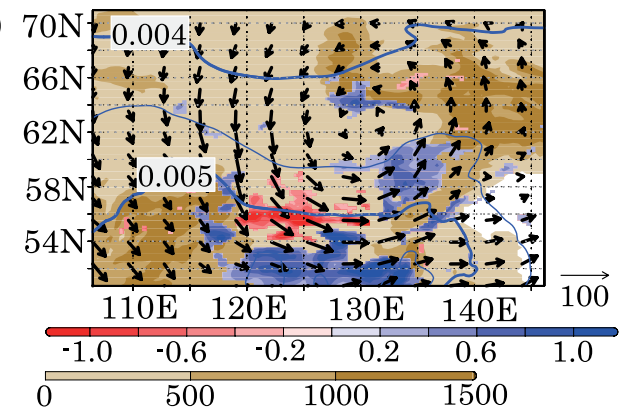

Fig. 4. JJA mean meteorological field without the three mountain range runs. (a) NVM run, (b) NDM run, and (c) NSM run. Blue/ red shading marks the area with increased/decreased precipitation for removal of the mountain range (mountain range removal run - CTL run, mm day ${ }^{-1}$ ). The vectors denote vertically integrated water vapor flux $\left(\mathrm{kg} \mathrm{m}^{-2} \mathrm{~s}^{-1}\right)$. The blue contours show specific humidity at $750 \mathrm{hPa}\left(\mathrm{kg} \mathrm{kg}^{-1}\right)$; the brown shades show elevation (m).

removal was quite a few compared to that of other two Mountain Ranges. The elevation was decreased to $200 \mathrm{~m}$ from $64^{\circ} \mathrm{N}$ to 70 ${ }^{\circ} \mathrm{N}$. However, precipitation did not change as much as it did in the NSM run. The lack of response is attributable to the original small precipitation amount on the Verkhoyansk Mountain Range. Although precipitation was around $2 \mathrm{~mm} \mathrm{day}^{-1}$ in the Stanovoy Mountain Range, it was $1.5 \mathrm{~mm} \mathrm{day}^{-1}$ in the Verkhoyansk Mountain Range area. Consequently, the Verkhoyansk Mountain Range impact on precipitation on a regional scale was small compared with that on the other two mountain ranges.

\subsection{Dzhugdzhur mountain range}

Figure $4 \mathrm{~b}$ shows the precipitation, vertical integrated water vapor flux, and the specific humidity field for the NDM run. As was true for the NVM run, enhanced precipitation over the Dzhugdzhur Mountain Range, which had occurred in the CTL run, was absent in for the NDM run. The range of precipitation decrease was 0.2 to $0.8 \mathrm{~mm} \mathrm{day}{ }^{-1}$. The maximum value was found in the south and northwest of the target area, which had steep topography. The precipitation decrease shows good agreement with topography removal. Therefore, precipitation over the Dzhugdzhur Mountain Range was also caused by an orographic effect.

The distribution of specific humidity was affected by the existence of the Dzhugdzhur Mountain Range. Specific humidity at $750 \mathrm{hPa}$ was $0.005 \mathrm{~kg} \mathrm{~kg}^{-1}$ in the southern part of the Dzhugdzhur Mountain Range and $0.004 \mathrm{~kg} \mathrm{~kg}^{-1}$ in the northern part of the NDM run. It was $0.0045-0.005 \mathrm{~kg} \mathrm{~kg}^{-1}$ over the whole (a) NVM
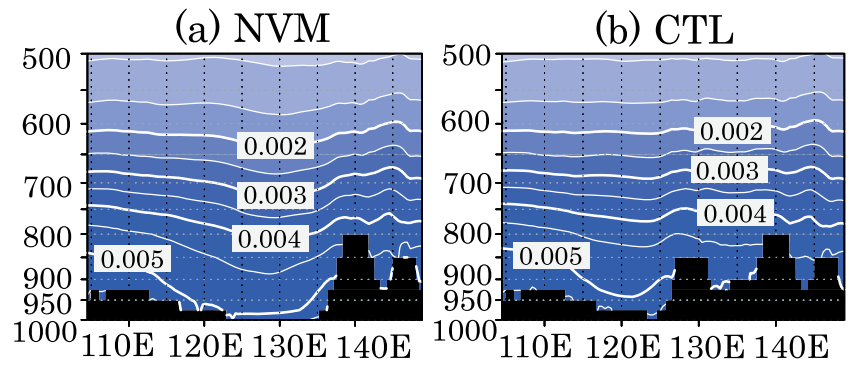

Fig. 5. Specific humidity (a) along $66^{\circ} \mathrm{N}$ for the NVM run: (b) is the same as (a), but for the CTL run $\left(\mathrm{kg} \mathrm{kg}^{-1}\right)$; black shading shows topography.

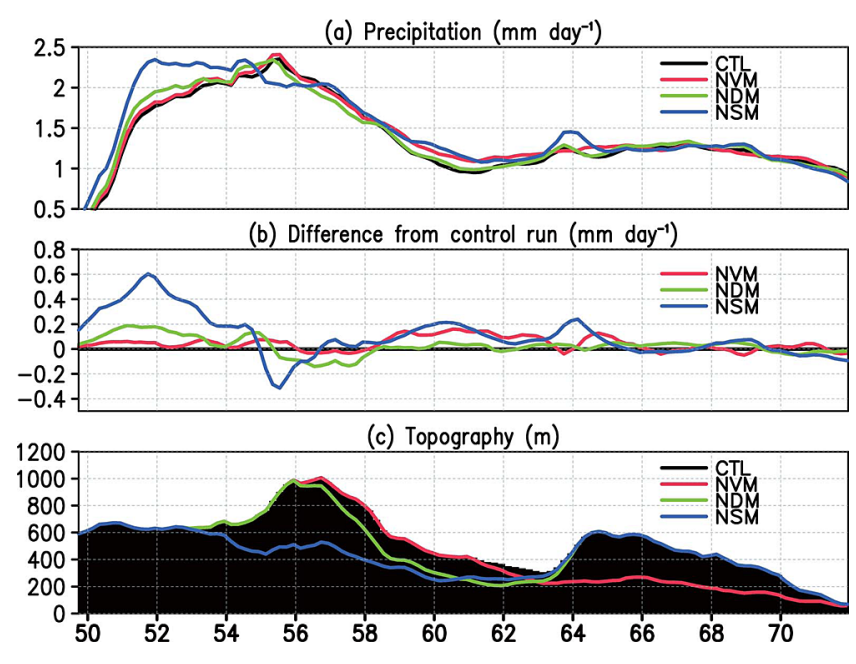

Fig. 6. Zonal mean from $110^{\circ} \mathrm{E}$ to $140^{\circ} \mathrm{E}$ of (a) Daily precipitation $\left(\mathrm{mm} \mathrm{day}^{-1}\right)$, (b) Difference from CTL run $\left(\mathrm{mm} \mathrm{day}^{-1}\right)$ and (c) Topography (m). The horizontal axis denotes latitude (degrees $\mathrm{N}$ ); the black shade shows the zonal mean elevation $(\mathrm{m})$.

Dzhugdzhur Mountain Range for the CTL run (not shown). This drying effect resulted from removal of the blocking effect of the water vapor flux. The Dzhugdzhur Mountain Range blocked the water vapor flux from the west and south by inducing orographic precipitation. This effect disappeared because of removal of the Dzhugdzhur Mountain Range.

For the NDM run, precipitation decrease was found in $56-58 \mathrm{~N}$ (Fig. 6b). This trend was generated by direct effect of removal mountain range and indirect effect over Stanovoy mountain range (Fig. 4b). Precipitation decrease of northwest part of Dzhugdzhur mountain range was not found in Fig. $6 \mathrm{~b}$ because increase of precipitation occurred in northeast part. The precipitation decrease trend is weak same as Verkhoyansk mountain range. Specific humidity over Dzhugdzhur is higher than that of Verkhoyansk mountain range, however, precipitation decrease was not clear in Fig. 6b. It was caused by relatively low elevation of Dzhugdzhur compared with other mountain ranges. Elevation is the key of orographic precipitation, thus impact of removal Dzhugdzhur mountain range was weak to north-south precipitation gradient.

\subsection{Stanovoy mountain range}

Figure $4 \mathrm{c}$ shows the NSM run case. The precipitation area shifted southward. The northern part of the Stanovoy Mountain Range was an area in which precipitation decreased; the southern part is an area of precipitation increase because of the mountain removal. The northern/southern part showed decreased/increased area because the water vapor flux direction in the NSM run deflected southward in the middle Lena Basin. Consequently, 
the water vapor that impacted the northern part of the Stanovoy Mountain Range in the CTL run was shifted to the southern area because of removal of the Stanovoy Mountain Range. Effects of the southward shifting of precipitation were also found in terms of the specific humidity field: the specific humidity over the Stanovoy Mountain Range was $0.005-0.0055 \mathrm{~kg} \mathrm{~kg}^{-1}$ for the CTL run decreasing to $0.0045-0.005 \mathrm{~kg} \mathrm{~kg}^{-1}$. The high specific humidity area shifted southward for the NSM run. When we specifically examined areas where precipitation decreased, precipitation decreased overall of Stanovoy mountain ranges thus orographic precipitation was dominant in this mountain range.

In Fig. 6a, the amount of precipitation change was not large, but precipitation reached $2.3 \mathrm{~mm}$ day $^{-1}$ south of the $54^{\circ} \mathrm{N}$ area for the NSM run. It was a side effect of Stanovoy Mountain Range removal. As shown in Fig. 6c, the elevation of the CTL run was $400-1000 \mathrm{~m}$ between $54^{\circ} \mathrm{N}$ and $60^{\circ} \mathrm{N}$, but it was less than $500 \mathrm{~m}$ for the NSM. Northerly winds were enhanced in the NSM run. Therefore, precipitation shifted southward. It was enhanced south of the Stanovoy Mountain Range. The salient point in Fig. 6b is where precipitation is decreased because the area in which precipitation increased is regarded as an area created by removal of the mountain range. In the NSM run, the precipitation decrease at $55^{\circ} \mathrm{N}$ is with the maximum value of $0.3 \mathrm{~mm} \mathrm{day}^{-1}$ in Fig. $6 \mathrm{~b}$. The area in which precipitation decreased shows good agreement with the area in which elevation decreased for the NSM run.

With removal of Stanovoy mountain range, southward component of water vapor flux could inflow easily to the region (Fig. 4c). Southward water vapor flux converged with inflow from southern boundary and its direction changed to eastward. Some component proceeded to southeast of Dzhugdzhur mountain range and some component made orographic precipitation in western part of Dzhugdzhur mountain range. Residual water vapor flux changed direction to northward and generated orographic precipitation in southern part of Verkhoyansk mountain range. As a result, counterclockwise circulation of water vapor flux was generated. Water source which fell over Stanovoy mountain range generated orographic precipitation in Dzhugdzhur and Verkhoyansk mountain ranges.

\section{Conclusions}

In this study, the degree to which precipitation changes with removal of three eastern Siberia mountain ranges (Verkhoyansk Mountain Range, Dzhugdzhur Mountain Range and Stanovoy Mountain Range) was examined through comparison of numerical simulations with and without mountain ranges. The Stanovoy Mountain Range strongly affects the north-south precipitation gradient. However, the effects of Verkhoyansk and Dzhugdzhur Mountain Range were not so large. The reason was different between two mountain ranges; lower specific humidity for Verkhoyansk, lower elevation for Dzhugdzhur caused weak impact to north-south precipitation gradient.

We found effects of mountain ranges on precipitation, however, the decreased precipitation with removal was not so significant. Probably, precipitation is defined by a wider area. For example, we selected the Stanovoy Mountain Range as the southern target. However, the possibility exists that precipitation of the southern area is controlled not only by the Stanovoy Mountain Range, but also by surrounding areas such as its western mountain range. Numerical simulations including a wider area are needed for understanding the water field in eastern Siberia. Moreover, numerical simulations were conducted for summer only, therefore further studies should be conducted for other seasons.

\section{Acknowledgments}

This study was supported by Research Project No. C-07 of the Research Institute for Humanity and Nature (RIHN), entitled "Global Warming and the Human-Nature Dimension in Siberia: Social Adaptation to the Changes of the Terrestrial Ecosystem, with Emphasis on Water Environments" (PI: Tetsuya Hiyama). Calculations were conducted using the Japan Meteorological Agency Nonhydrostatic Model, developed by the Meteorological Research Institute and the Numerical Prediction of the Japan Meteorological Agency. We thank Dr. Tetsuya Hiyama of the Research Institute for Humanity and Nature, Professor Toshiki Iwasaki, Dr. Weiming Sha and Mr. Shota Ishii of Tohoku University for their useful and constructive comments. Constructive and careful comments by Dr. John E. Walsh and two anonymous reviewers have been valuable for revising the manuscript.

\section{References}

Frey, K. E., and L. C. Smith, 2003: Recent temperature and precipitation increases in West Siberia and their association with the Arctic Oscillation. Polar Research, 22, 287-300.

Fukutomi, Y., K. Masuda, and T. Yasunari, 2007: Cyclone acrivity associated with the interannual seesaw oscillation of summer precipitation over northern Eurasia. Global and Planetary Change, 56, 387-398.

Iwao, K., and M. Takahashi, 2008: A precipitation seesaw mode between northeast Asia and Siberia in summer caused by Rossby waves over the Eurasian continent. J. Climate, 21, 2401-2419.

Kain, J. S., 2004: The Kain-Fritsch convective parameterization: An update. J. Appl. Meteor., 43, 170-181.

Kurita, N., N. Yoshida, G. Inoue, and E. A. Chayanova, 2004: Modern isotope climatology of Russia: A first assessment. $J$. Geophys. Res., 109, D03102, doi:10.1029/2003JD003404.

Nakanishi, M., and H. Niino, 2004: An improved Mellor-Yamada level-3 model with condensation physics: Its design and verification. Bound.-Layer Meteor., 112, 1-31.

Onogi, K., J. Tsutsui, H. Koike, M. Sakamoto, S. Kovayashi, H. Hatsushika, T. Matsumoto, N. Yamazaki, H. Kamahori, K. Takahashi, S. Kadokura, K. Wada, K. Kato, R. Oyama, T. Ose, N. Mannoji, and R. Taira, 2007: The JRA-25 reanalysis. J. Meteor. Soc. Japan, 85, 369-432.

Saito, K., J. Ishida, K. Aranami, T. Hara, T. Segawa, M. Narita, and Y. Honda, 2007: Nonhydrostatic atmospheric models and operational development at JMA. J. Meteor. Soc. Japan, 85B, 271-304.

Suzuki, R., S. Tanaka, and T. Yasunari, 2000: Relationships between meridional profiles of satellite-derived vegetation index (NDVI) and climate over Siberia. Int. J. Climatol., 20, 955-967.

Suzuki, R., T. Hiyama, J. Asamuna, and T. Ohata, 2004: Land surface identification near Yakutsk in eastern Siberia using video images taken from a hedgehopping aircraft. Int. J. Remote Sen., 25, 4015-4028.

U. S. Geological Survey, 1996: GTOPO30 global digital elevation model. Sioux Falls, South Dakota, EROS DATA Center.

van der Ent, R. J., H. H. G. Savenije, B. Schaefli, and S. C. SteeleDunne, 2010: Origin and fate of atmospheric moisture over continents. Water Resour. Res., 46, W09525, doi: 10.1029/ 2010WR009127R.

Manuscript received 14 July 2011, accepted 6 September 2011

SOLA: http://www.jstage.jst.go.jp/browse/sola 